\title{
Body image assessment and quality of life in patients with atopic dermatitis
}

\section{Ocena obrazu ciała i jakości życia pacjentów z atopowym zapaleniem skóry}

Joanna Mikołajczyk', Teresa Rzepa', Joanna Król', Ryszard Żaba ${ }^{3}$

'University of Social Sciences and Humanities, Faculty in Poznan, Poland

Institute of Psychology, University of Szczecin, Poland

${ }^{3}$ Department of Dermatology and Venereology, Poznan University of Medical Sciences, Poznan, Poland

'Uniwersytet Humanistycznospołeczny SWPS, Wydział Zamiejscowy w Poznaniu, Polska

2Instytut Psychologii Uniwersytetu Szczecińskiego, Polska

${ }^{3}$ Katedra Dermatologii i Wenerologii Uniwersytetu Medycznego w Poznaniu, Polska

Dermatol Rev/Przegl Dermatol 2017, 104, 92-102

DOl: https://doi.org/l0.5 | |4/dr.2017.67383

\author{
CORRESPONDING AUTHOR/ \\ ADRES DO KORESPONDENCJI: \\ Joanna Król \\ Instytut Psychologii \\ Uniwersytet Szczeciński \\ ul. Krakowska 69 \\ 71-017 Szczecin, Poland \\ e-mail: krol-joanna@wp.pl
}

\begin{abstract}
Introduction. Atopic dermatitis is a chronic and recurrent inflammatory skin condition. Significant skin lesions caused by the condition contribute to a negative perception of one's body. A negative body image may cause or enhance negative mental state, which, in a vicious circle, contributes to aggravation of the disease symptoms and deterioration of life quality. Especially skin lesions occurring on visible parts of the body may lead to a lack of acceptance by other people.

Objective. To determine the impact of body image on the life quality evaluation of patients with atopic dermatitis.

Material and methods. The study included 59 patients (36 women and 23 men) with atopic dermatitis. The patients completed the Multidimensional Body-Self Relations Questionnaire, which measures the general body image perception, the Dermatology Quality of Life Index and a personal survey.

Results and conclusions. Among the patients with atopic dermatitis, the general body image evaluation was not correlated with the perceived life quality, though some statistically significant correlations were found between this variable and four body image dimensions. No statistically significant differences were found between men and women with regard to life quality assessment, but it was found that the women differed from the men statistically significantly with regard to the following dimensions of body image: Health Orientation ( $p=$ $0.0344)$ and Overweight Preoccupation $(p=0.0155)$. Moreover, illness duration was shown to have an impact on life quality assessment as well as on the two following dimensions of body image: Appearance Orientation and Health Evaluation.
\end{abstract}

\section{STRESZCZENIE}

Wprowadzenie. Atopowe zapalenie skóry jest przewlekłym i nawracającym stanem zapalnym skóry. Zmiany skórne występujące w przebiegu atopowego zapalenia skóry przyczyniają się do negatywnego postrzegania własnego ciała. Negatywny obraz własnego ciała może 
wywołać i potęgować negatywne stany emocjonalne, co powoduje zaostrzenie objawów choroby i pogorszenie jakości życia. Zwłaszcza obecność zmian zlokalizowanych na skórze odsłoniętej sprawia, że chory może się spotkać z brakiem akceptacji ze strony otoczenia.

Cel pracy. Określenie wpływu obrazu własnego ciała na ocenę jakości życia u pacjentów z atopowym zapaleniem skóry.

Materiał i metodyka. W badaniu wzięło udział 59 pacjentów (36 kobiet i 23 mężczyzn) z atopowym zapaleniem skóry. Zastosowano Wielowymiarowy Kwestionariusz do Badania Obrazu Ciała, Wskaźnik Wpływu Dolegliwości Skórnych na Jakość Życia oraz ankietę osobową.

Wyniki i wnioski. U pacjentów z atopowym zapaleniem skóry ogólna ocena obrazu własnego ciała nie ma związku z poczuciem jakości życia. Wykazano statystycznie istotną korelację między poczuciem jakości życia i czterema wymiarami obrazu własnego ciała. Nie stwierdzono statystycznie istotnych różnic pomiędzy kobietami i mężczyznami w zakresie oceny jakości życia oraz stwierdzono, że kobiety różnią się statystycznie istotnie od mężczyzn w zakresie takich wymiarów obrazu swego ciała, jak Zorientowanie na Zdrowie $(p=0,0344)$ i Zaabsorbowanie Nadwagą $(p=0,0155)$. Wykazano ponadto wpływ czasu trwania choroby na ocenę jakości własnego życia oraz na dwa wymiary obrazu własnego ciała: Zorientowanie na Wygląd i Ocenę Zdrowia.

Key words: atopic dermatitis, body image, quality of life.

Słowa kluczowe: atopowe zapalenie skóry, obraz ciała, jakość życia.

\section{INTRODUCTION}

The condition of skin, hair and nails not only provides information on the person's health, but also has an impact on his or her body image development, self-assessment, self-acceptance and self-esteem. Therefore, it plays a significant role in the socialization process and ensures effective functioning in society.

Healthy skin tends to invoke admiration and acceptance, whereas diseased skin is likely to incite aversion, fear, prejudice and revulsion. Atopic dermatitis (AD) is one of the chronic skin diseases that are difficult to treat and that trigger negative emotional reactions. The disease is manifested by occurrence of hardly separated, erythematous lesions accompanied by lichenification, papules, and, as secondary symptoms, excoriations and erosions [1]. The somatic symptoms of the disease include burning sensation, pain and itching, which dramatically decrease the affected person's life quality. Itching impairs sleep, which leads to chronic fatigue, lowers the mood and disturbs everyday functioning. The disease exacerbation may be caused by environmental factors (air pollution, infections, etc.) as well as mental factors, especially those connected with stress [2]. Keeping the skin clear from the disease symptoms requires close cooperation between the patient and the physi-

\section{WPROWADZENIE}

Kondycja skóry, włosów i paznokci nie tylko informuje o stanie zdrowia, lecz także wpływa na kształtowanie obrazu własnego ciała, samoocenę i poczucie własnej wartości, przez co odgrywa istotną rolę $\mathrm{w}$ procesie socjalizacji i zapewnia efektywne funkcjonowanie w otoczeniu społecznym.

Zdrowa skóra może wzbudzać wrażenie piękna, a skóra chora - niechęć i odrazę. Jedną z przewlekłych i trudnych do wyleczenia chorób skóry jest atopowe zapalenie (AZS), które objawia się występowaniem słabo odgraniczonych, rumieniowych zmian z towarzyszącą lichenifikacją, obecnością grudek, a wtórnie przeczosów oraz nadżerek [1]. Do objawów somatycznych należą: pieczenie i bolesność skóry oraz świąd, który dramatycznie obniża jakość życia. Świąd upośledza sen, wpływa na uczucie chronicznego zmęczenia, obniża nastrój i zaburza ogólne funkcjonowanie. Zaostrzenie choroby mogą powodować czynniki środowiskowe (zanieczyszczenia powietrza, zakażenia itp.) oraz obciążenia psychiczne, zwłaszcza powiązane ze stresem [2]. Utrzymanie skóry w stanie bezobjawowym wymaga ścisłej współpracy z lekarzem i zaangażowania w kosztowny proces leczenia, który obejmuje: zakup specjalnych ubrań, bielizny pościelowej, leków, 
cian, as well as engaging in a costly treatment process that involves purchasing special clothes, bed sheets, medicines, washing powders, cosmetics and skin care products [3].

Skin diseases rarely constitute a direct risk to life or health. Therefore, problems of dermatological patients tend to be disregarded, even though skin diseases are qualified as life-ruining conditions due to their chronic, bothersome nature and visible symptoms [4]. The skin lesions cause intense stress and invoke a stigmatization feeling, because they may be considered by other people to be contagious and a result of insufficient hygiene or neglect of personal care [5-7]. Negative reactions from society observed by patients may cause secondary stress and consequently trigger a vicious circle mechanism. Dermatological patients often assess their ailments as very troublesome, comparable to those suffered by persons with coronary disease, asthma or diabetes [8].

Atopic dermatitis has a negative impact on life quality. This is because the illness changes the body image and hinders the functioning in the home, school or occupational contexts, decreases self-esteem, destroys self-confidence and gives rise to fear of being rejected by society. It was found that more than half of AD patients experienced depressive disorders or felt unhappy due to their condition, and some even reported having suicidal thoughts [9]. Especially the skin lesions that are located in visible places (such as hands, face) make AD patients likely to experience both disapproval and ostracism from society and to unfavourably modify their body image.

A positive body image is associated with adequate self-assessment, self-confidence, feelings of happiness and psychosocial well-being [10]. Persons who are satisfied with their appearance tend to positively assess their interpersonal relations and do not avoid social contacts. Being dissatisfied with one's body, in turn, tends to distort its perception and leads to negative beliefs regarding oneself, resulting in underestimated self-assessment, lack of self-acceptance, low self-esteem, and consequently isolating oneself from other people $[9,11]$. The rejecting reactions of society usually intensify any negative mental states which reciprocally - by the vicious circle mechanism - lead to exacerbation of the disease symptoms. All these factors make dermatological patients particularly sensitive to their appearance, and they tend to assess their life quality as bad.

\section{OBJECTIVE}

We decided to find out: 1 ) whether there is a correlation between body image evaluation and perceived life quality in AD patients; 2) whether there is a difference between male and female AD patients in terms of body image evaluation and perceived life quality; proszków do prania, kosmetyków i środków pielęgnacyjnych [3].

Choroby skóry rzadko stanowią bezpośrednie zagrożenie dla zdrowia i życia. Stąd bierze się tendencja do bagatelizowania problemów pacjentów dermatologicznych. Tymczasem z powodu przewlekłości, widoczności i dokuczliwości objawów choroby skóry zalicza się do kategorii schorzeń rujnujących życie [4]. Zmiany skórne są przyczyną silnego stresu i wywołują poczucie stygmatyzacji, ponieważ mogą być odbierane jako zakaźne, wynikające z braku higieny czy zaniedbania [5-7]. Obserwowane przez chorych negatywne reakcje ze strony otoczenia mogą być powodem wtórnego stresu, a tym samym uruchamiać mechanizm błędnego koła. Pacjenci dermatologiczni oceniają swoje dolegliwości jako bardzo uciążliwe, porównywalne z doświadczanymi przez osoby z chorobą wieńcową, astmą czy cukrzycą [8].

Atopowe zapalenie skóry negatywnie wpływa na jakość życia. Choroba zmienia obraz własnego ciała, ogranicza możliwość wykonywania obowiązków domowych, szkolnych i zawodowych, obniża samoocenę, niszczy pewność siebie i jest źródłem lęku przed odrzuceniem społecznym. Ustalono, że ponad połowa pacjentów z AZS doświadcza depresji lub czuje się nieszczęśliwa z powodu swojego stanu, a niektórzy zgłaszają nawet myśli samobójcze [9]. Zwłaszcza zmiany skórne zlokalizowane w widocznych miejscach (np. na rękach, twarzy) sprawiają, że chory może się spotkać z brakiem akceptacji i ostracyzmem ze strony otoczenia, jak również dokonać niekorzystnej modyfikacji obrazu własnego ciała.

Pozytywny obraz własnego ciała wiąże się z adekwatną samooceną, pewnością siebie i poczuciem osobistego szczęścia [10]. Osoby zadowolone ze swojego wyglądu pozytywnie oceniają relacje interpersonalne i nie stronią od kontaktów z innymi ludźmi. Niezadowolenie z własnego ciała może zaburzać jego percepcję i prowadzić do negatywnych przekonań, skutkujących zaniżoną samooceną, niskim poczuciem własnej wartości oraz izolowaniem się od innych ludzi $[9,11]$. Odtrącające reakcje ze strony otoczenia społecznego mogą pogłębiać negatywne stany psychiczne, które zwrotnie - na zasadzie mechanizmu błędnego koła - powodują zaostrzenie symptomów chorobowych. Wszystko to sprawia, że pacjenci dermatologiczni w sposób szczególny odnoszą się do własnego wyglądu i z reguły nisko oceniają jakość swojego życia.

\section{CEL PRACY}

Postanowiono sprawdzić: 1) czy istnieje związek między oceną obrazu własnego ciała a poczuciem jakości życia u osób z AZS; 2) czy kobiety i mężczyźni chorujący na AZS różnią się w zakresie oceny obrazu 
3) whether the illness duration has an impact on both variables, i.e. body image and perceived life quality.

\section{MATERIAL AND METHODS}

The study was performed in 2015 and it involved 59 subjects: 36 women and 23 men affected by AD. The age span was from 18 to 46 years, and the mean age for the whole group of subjects was 26.9 years (standard deviation, $S D=6.80$ ), in the case of the women the mean was 25.6 years $(S D=5.95)$, and for the men it was 28.9 years $(S D=7.67)$. The shortest duration of the disease was half a year, the longest 46 years. The mean duration of the disease was 15.1 years $(S D=10.98)$. Among the female patients, this value was 14.6 years $(S D=9.74)$, and among the men it was 15.8 years $(S D=12.87)$.

The research study was implemented with consent no. 193/15 of 5 February 2015, granted by the Research Ethics Committee at the Poznań University of Medical Sciences.

First, the subjects were asked to fill in the Multidimensional Body-Self Relations Questionnaire (MBSRQ) [12], Polish adaptation by Katarzyna Schier and associates [13]. This tool encompasses 69 items to evaluate the subjects' attitude to their body image and function, and includes the following scales: Appearance Evaluation, Appearance Orientation, Fitness Evaluation, Fitness Orientation, Health Evaluation, Health Orientation, Illness Orientation, Body Areas Satisfaction, Overweight Preoccupation and Self-classified Weight. The evaluation applied a Likert 5-grade scale where 1 meant "I definitely disagree" or "nev$\mathrm{er}^{\prime \prime}$, and 5 meant "I definitely agree" or "very often". In the case of items concerning weight, 1 meant "serious underweight", and 5 meant "obesity".

The next questionnaire to be filled in was the Dermatology Life Quality Index (DLQI). This is a self-description method devised by Andrew Y. Finlay and Gul Karim Khan [14]. The Polish adaptation of this research tool was done by Jacek Szepietowski et al. [15]. The method applies 10 questions to evaluate (on a scale from 0 to 3 points) the degree of disability caused by the dermatological disease. The higher the score, the stronger is the impact of the sustained ailments on life quality. The contents of the questions refer to the patients' functioning in the following areas: everyday activity, leisure time, work or school, family and social relations, and sex life.

\section{Statistical analysis}

The statistical computations were performed using Statistica PL v. 10.0 software by StatSoft. Consistency with normal distribution was checked with the Shapiro-Wilk test. Where consistency with the Gaussian distribution curve was found, Student's $t$-test was własnego ciała oraz poczucia jakości życia; 3) czy czas trwania choroby różnicuje obie zmienne.

\section{MATERIA $~ I$ METODYKA}

W badaniu przeprowadzonym w 2015 r. uczestniczyło 59 osób, w tym 36 kobiet i 23 mężczyzn chorych na AZS. Rozpiętość wieku sięgała od 18 do 46 lat, a średnia wieku ogółu badanych wynosiła 26,9 roku (odchylenie standardowe, $S D=6,80$ ), dla kobiet $-25,6$ roku $(S D=5,95)$, natomiast dla mężczyzn - 28,9 roku $(S D=7,67)$. Najkrótszy okres chorowania wynosił pół roku, a najdłuższy - 46 lat. Średni czas trwania choroby wynosił 15,1 roku $(S D=10,98)$. U badanych kobiet wartość ta wynosiła 14,6 roku $(S D=9,74)$, a u mężczyzn - 15,8 roku $(S D=12,87)$.

Badania przeprowadzono za zgodą Komisji Bioetycznej przy Uniwersytecie Medycznym im. Karola Marcinkowskiego w Poznaniu, nr 193/15 z 5 lutego 2015 r.

W pierwszej kolejności pacjenci wypełnili Wielowymiarowy Kwestionariusz do Badania Obrazu Ciała (MBSRQ) [12], w polskiej adaptacji Katarzyny Schier i jej współpracowników [13]. Narzędzie składa się z 69 pozycji oceniających stosunek osób badanych do obrazu i funkcji i obejmuje następujące skale: Ocena Wyglądu, Zorientowanie na Wygląd, Ocena Sprawności, Zorientowanie na Sprawność, Ocena Zdrowia, Zorientowanie na Zdrowie, Zorientowanie na Choroby, Satysfakcja z Obszarów Ciała, Zaabsorbowanie Nadwagą i Ocena Własnej Wagi. Ocen dokonuje się za pomocą 5-stopniowej skali Likerta, gdzie 1 oznacza "zdecydowanie się nie zgadzam” bądź „nigdy”, a 5 "zdecydowanie się zgadzam” bądź „bardzo często". W przypadku pozycji dotyczących wagi 1 oznacza "bardzo dużą niedowagę", a 5 - "otyłość".

Następnie wypełniano Wskaźnik Wpływu Dolegliwości Skórnych na Jakość Życia (DLQI). Jest to metoda samoopisowa autorstwa Andrew Y. Finlaya i Gula Karima Khana [14]. Polskiej adaptacji tego narzędzia badawczego dokonali Jacek Szepietowski i wsp. [15]. Składa się ono z 10 pytań pozwalających na ocenę (w skali od 1 do 3 punktów) stopnia niesprawności spowodowanej przez chorobę dermatologiczną. Im wyższy jest wynik, tym silniejszy wpływ doświadczanych dolegliwości na jakość życia. Treść pytań odnosi się do funkcjonowania w następujących dziedzinach: codzienne formy aktywności, czas wolny, praca lub szkoła, relacje rodzinne i towarzyskie oraz życie seksualne.

\section{Analiza statystyczna}

Analizę statystyczną wykonano za pomocą programu Statistica PL, wersja 10.0 firmy StatSoft. Zgodność z rozkładem normalnym sprawdzono za pomocą testu Shapiro-Wilka. W przypadku zgod- 
applied; otherwise the Mann-Whitney test was used. Correlations between the variables were verified by means of Pearson's correlation coefficient or Spearman's rank correlation coefficient. Results were considered statistically significant at $p<0.05$.

\section{RESULTS}

It was found that the general evaluation of body image among the AD patients was not correlated with the perceived life quality. However, statistically significant correlations were observed between life quality assessment and the following dimensions of body image:

- Health Evaluation and Body Areas Satisfaction with regard to all the subjects $(r=-0.48)$ and to the women $(r=-0.50)$ and men $(r=-0.44)$ respectively, - Appearance Evaluation with regard to all the subjects $(r=-0.29)$ and the men $(r=-0.49)$,

- Appearance Orientation with regard to all the subjects $(r=0.29)$ and the women $(r=0.35)$,

- Health Orientation with regard to all the subjects $(r=0.31)$ and the women $(r=0.39)$ (Tables 1 and 2$)$. There was no statistically significant difference $(p=0.6603)$ between the women (arithmetic mean, $M=9.81 ; S D=7.94)$ and the men $(M=9.43 ; S D=8.61)$ in terms of life quality assessment. Also, it was found that the women differed statistically significantly from the men in terms of the following dimensions of body image: Health Orientation ( $p=0.0344$; women: $M=3.66 ; S D=0.69$; men: $M=3.26 ; S D=0.58)$ and Overweight Preoccupation ( $p=0.0155$; women: $M=2.82 ; S D=0.97$; men: $M=2.17 ; S D=0.76$ ) (Table 3).

Moreover, the impact of the illness duration on life quality assessment $(r=0.29)$, as well as on two ności z krzywą Gaussa wykonano test $t$-Studenta, a w przypadku jej braku - test Manna-Whitneya. Zależności między zmiennymi weryfikowano za pomocą współczynnika korelacji Pearsona lub współczynnika korelacji rang Spearmana. Wyniki uznano za istotne statystycznie przy $p<0,05$.

\section{WYNIKI}

Stwierdzono, że u pacjentów z AZS ogólna ocena obrazu własnego ciała nie ma związku z poczuciem jakości życia. Statystycznie istotne korelacje wykazano natomiast między oceną jakości życia a następującymi wymiarami obrazu własnego ciała:

- Ocena Zdrowia i Satysfakcja z Obszarów Ciała - dla ogółu pacjentów $(r=-0,48)$ oraz odpowiednio dla kobiet $(r=-0,50)$ i mężczyzn $(r=-0,44)$,

- Ocena Wyglądu - dla ogółu pacjentów $(r=-0,29)$ i mężczyzn $(r=-0,49)$,

- Zorientowanie na Wygląd - dla ogółu pacjentów $(r=0,29)$ oraz kobiet $(r=0,35)$,

- Zorientowanie na Zdrowie - dla ogółu pacjentów $(r=0,31)$ i kobiet $(r=0,39)$ (tabele 1 i 2$)$.

Stwierdzono brak statystycznie istotnych różnic $(p=0,6603)$ pomiędzy kobietami $(M=9,81 ; S D=7,94)$ i mężczyznami $(M=9,43 ; S D=8,61)$ co do poczucia jakości życia. Kobiety różnią się natomiast statystycznie istotnie ( $p=0,0344$ ) od mężczyzn w zakresie wymiaru Zorientowanie na Zdrowie (odpowiednio kobiety: $M=3,66$; $S D=0,69$ oraz mężczyźni $M=3,26$; $S D=$ $0,58)$ oraz Zaabsorbowanie Nadwagą $(p=0,0155$; kobiety: $M=2,82 ; S D=0,97$; mężczyźni: $M=2,17$; $S D=0,76)$ (tabela 3).

Wykazano ponadto wpływ czasu trwania choroby na poczucie jakości życia $(r=0,29)$ oraz na dwa wy-

Table I. Characteristics of patients with atopic dermatitis

Tabela I. Charakterystyka badanej grupy pacjentów z atopowym zapaleniem skóry

\begin{tabular}{|c|c|c|c|c|c|c|}
\hline Parameter/Parametr & $N$ & M & Med. & Min. & Max. & $S D$ \\
\hline Age/wiek & 59 & 26.86 & 25.00 & 18.00 & 49.00 & 6.80 \\
\hline $\begin{array}{l}\text { Illness duration (since the diagnosis)/czas trwania } \\
\text { choroby (od rozpoznania) }\end{array}$ & 59 & 15.06 & 16.00 & 0.50 & 46.00 & 10.98 \\
\hline Appearance Evaluation ${ }^{a} /$ Ocena Wyglądu $^{a}$ & 59 & 3.13 & 3.29 & 1.00 & 4.57 & 0.95 \\
\hline Appearance Orientation $/$ /Zorientowanie na Wyglą ${ }^{\mathrm{a}}$ & 59 & 3.37 & 3.42 & 1.92 & 4.58 & 0.56 \\
\hline Fitness Evaluationa/Ocena Sprawnościa & 59 & 3.37 & 3.67 & 1.00 & 5.00 & 1.02 \\
\hline Fitness Orientation ${ }^{a} / Z$ orientowanie na Sprawnośća & 59 & 3.20 & 3.08 & 1.00 & 5.00 & 0.94 \\
\hline Health Evaluation ${ }^{\mathrm{a}}$ Ocena Zdrowia ${ }^{\mathrm{a}}$ & 59 & 2.83 & 2.83 & 1.17 & 4.83 & 0.83 \\
\hline Health Orientation ${ }^{\mathrm{a}} /$ Zorientowanie na Zdrowie ${ }^{\mathrm{a}}$ & 59 & 3.50 & 3.50 & 1.50 & 4.88 & 0.68 \\
\hline Illness Orientationa/Zorientowanie na Choroby ${ }^{\mathrm{a}}$ & 59 & 3.36 & 3.20 & 1.20 & 4.80 & 0.74 \\
\hline Body Areas Satisfactiona/Satysfakcja z Obszarów Ciała ${ }^{a}$ & 59 & 3.21 & 3.33 & 1.78 & 4.56 & 0.61 \\
\hline Overweight Preoccupation ${ }^{\mathrm{a}} /$ Zaabsorbowanie Nadwagą ${ }^{\mathrm{a}}$ & 59 & 2.57 & 2.50 & 1.00 & 4.75 & 0.94 \\
\hline Self-classified Weighta/Ocena Własnej Wagia & 59 & 3.31 & 3.00 & 1.00 & 5.00 & 0.74 \\
\hline $\begin{array}{l}\text { Perceived quality of life accessed by DLQI/poczucie } \\
\text { jakości życia na podstawie DLQI }\end{array}$ & 59 & 9.66 & 8.00 & 0.00 & 30.00 & 8.14 \\
\hline
\end{tabular}

a accessed by MBSRQ; N - number of people, M - mean, Med. - median, Min. - minimum, Max. - maximum, SD - standard deviation. aoceniony za pomocą MBSRQ; N - liczba osób, M - średnia, Med. - mediana, Min. - minimum, Max. - maksimum, SD - odchylenie standardowe. 
Table 2. Correlations between body image evaluation and perceived quality of life (for all patients and broken down by gender)

Tabela 2. Korelacje między oceną obrazu własnego ciała a poczuciem jakości życia (dla ogółu badanych pacjentów oraz z podziałem na płeć)

\begin{tabular}{lccc}
$\begin{array}{l}\text { Body image evaluation accessed by MBSRQ and perceived quality } \\
\text { of life accessed by DLQI/Ocena obrazu własnego ciała w MBSRQ } \\
\text { a poczucie jakości życia na podstawie DLQI }\end{array}$ & $\begin{array}{c}\text { Total/Ogółem } \\
r\end{array}$ & $\begin{array}{c}\text { Men/Mężczyźni } \\
r\end{array}$ & $\begin{array}{c}\text { Women/Kobiety } \\
r\end{array}$ \\
$\begin{array}{l}\text { Appearance Evaluation/Ocena Wyglądu } \\
\text { Appearance Orientation/Zorientowanie na Wygląd }\end{array}$ & $-0.29 *$ & $-0.49 * *$ & -0.17 \\
\hline Fitness Evaluation/Ocena Sprawności & $0.29 *$ & 0.19 & $0.35^{*}$ \\
\hline Fitness Orientation/Zorientowanie na Sprawność & -0.15 & -0.4 & -0.01 \\
\hline Health Evaluation/Ocena Zdrowia & -0.07 & -0.24 & -0.01 \\
\hline Health Orientation/Zorientowanie na Zdrowie & $-0.48^{* *}$ & $-0.44 *$ & $-0.50^{* *}$ \\
\hline Illness Orientation/Zorientowanie na Choroby & $0.3 I^{*}$ & 0.18 & $0.39 *$ \\
\hline Body Areas Satisfaction/Satysfakcja z Obszarów Ciała & 0.15 & 0.16 & 0.13 \\
\hline Overweight Preoccupation/Zaabsorbowanie Nadwagą & $-0.48^{*}$ & $-0.47 *$ & $-0.42 *$ \\
\hline Self-classified Weight/Ocena Własnej Wagi & 0.17 & 0.26 & 0.1 \\
\hline
\end{tabular}

* $p<0.05$, ** $p<0.01 ; p$ - materiality level, $r$ - correlation coefficient.

* $p<0,05, * * * 0,01 ; p-$ poziom istotności, $r$ - współczynnik korelacji.

Table 3. General body image and its dimensions and perceived quality of life in patients broken down by gender

Tabela 3. Ogólny obraz własnego ciała i jego mymiary oraz poczucie jakości życia u badanych pacjentów z podziałem na płeć

\begin{tabular}{|c|c|c|c|c|c|c|c|c|}
\hline $\begin{array}{l}\text { Self-Appearance Evaluation accessed by MBSRQ/ } \\
\text { Ocena własnego wyglądu w MBSRQ }\end{array}$ & $\begin{array}{l}\text { Gender/ } \\
\text { Pleć }\end{array}$ & $N$ & $\begin{array}{l}\text { Mean/ } \\
\text { Średnia }\end{array}$ & Med. & Min. & Max. & $S D$ & $P$ \\
\hline \multirow[t]{2}{*}{ Appearance Evaluation/Ocena Wyglądu } & $M / M$ & 23 & 3.29 & 3.43 & 1.43 & 4.43 & 0.78 & \multirow[t]{2}{*}{0.4087} \\
\hline & $\mathrm{W} / \mathrm{K}$ & 36 & 3.02 & 3.21 & 1.00 & 4.57 & 1.05 & \\
\hline \multirow[t]{2}{*}{ Appearance Orientation/Zorientowanie na Wygląd } & $M / M$ & 23 & 3.32 & 3.25 & 2.42 & 4.17 & 0.51 & \multirow[t]{2}{*}{0.5321} \\
\hline & $\mathrm{W} / \mathrm{K}$ & 36 & 3.40 & 3.50 & 1.92 & 4.58 & 0.59 & \\
\hline \multirow[t]{2}{*}{ Fitness Evaluation/Ocena Sprawności } & $M / M$ & 23 & 3.48 & 3.67 & 1.67 & 5.00 & 0.86 & \multirow[t]{2}{*}{0.6603} \\
\hline & $\mathrm{W} / \mathrm{K}$ & 36 & 3.31 & 3.50 & 1.00 & 5.00 & 1.12 & \\
\hline \multirow[t]{2}{*}{ Fitness Orientation/Zorientowanie na Sprawność } & $M / M$ & 23 & 3.11 & 2.92 & 1.62 & 4.85 & 0.89 & \multirow[t]{2}{*}{0.4265} \\
\hline & $\mathrm{W} / \mathrm{K}$ & 36 & 3.25 & 3.27 & 1.00 & 5.00 & 0.98 & \\
\hline \multirow[t]{2}{*}{ Health Evaluation/Ocena Zdrowia } & $M / M$ & 23 & 2.79 & 2.83 & 1.17 & 4.50 & 0.80 & \multirow[t]{2}{*}{0.7992} \\
\hline & $\mathrm{W} / \mathrm{K}$ & 36 & 2.86 & 2.83 & 1.17 & 4.83 & 0.86 & \\
\hline \multirow[t]{2}{*}{ Health Orientation/Zorientowanie na Zdrowie } & $M / M$ & 23 & 3.26 & 3.38 & 2.00 & 4.25 & 0.58 & \multirow[t]{2}{*}{$0.0344^{*}$} \\
\hline & $\mathrm{W} / \mathrm{K}$ & 36 & 3.66 & 3.63 & 1.50 & 4.88 & 0.69 & \\
\hline \multirow[t]{2}{*}{ IIIness Orientation/Zorientowanie na Choroby } & $M / M$ & 23 & 3.23 & 3.20 & 2.00 & 4.60 & 0.63 & \multirow[t]{2}{*}{0.1703} \\
\hline & $\mathrm{W} / \mathrm{K}$ & 36 & 3.44 & 3.30 & 1.20 & 4.80 & 0.81 & \\
\hline \multirow[t]{2}{*}{ Body Areas Satisfaction/Satysfakcja z Obszarów Ciała } & $M / M$ & 23 & 3.34 & 3.33 & 1.78 & 4.56 & 0.64 & \multirow[t]{2}{*}{0.1265} \\
\hline & $\mathrm{W} / \mathrm{K}$ & 36 & 3.13 & 3.00 & 2.00 & 4.22 & 0.59 & \\
\hline \multirow[t]{2}{*}{ Overweight Preoccupation/Zaabsorbowanie Nadwagą } & $M / M$ & 23 & 2.17 & 2.00 & 1.25 & 3.25 & 0.76 & \multirow[t]{2}{*}{$0.0155^{*}$} \\
\hline & $\mathrm{W} / \mathrm{K}$ & 36 & 2.82 & 2.75 & 1.00 & 4.75 & 0.97 & \\
\hline \multirow[t]{2}{*}{ Self-classified Weight/Ocena Własnej Wagi } & $M / M$ & 23 & 3.24 & 3.00 & 1.00 & 4.50 & 0.71 & \multirow[t]{2}{*}{$0.649 \mid$} \\
\hline & $\mathrm{W} / \mathrm{K}$ & 36 & 3.35 & 3.50 & 1.50 & 5.00 & 0.77 & \\
\hline \multirow{2}{*}{$\begin{array}{l}\text { Perceived quality of life accessed by DLQI/poczucie jakości } \\
\text { życia na podstawie DLQI }\end{array}$} & $M / M$ & 23 & 9.43 & 8.00 & 0.00 & 30.00 & 8.61 & \multirow[t]{2}{*}{0.6603} \\
\hline & $\mathrm{W} / \mathrm{K}$ & 36 & 9.81 & 7.50 & 0.00 & 30.00 & 7.94 & \\
\hline
\end{tabular}

*p $<0.05 ; \mathrm{M}$ - men, $\mathrm{W}$ - women, $\mathrm{N}$ - number of people, Med. - median, Min. - minimum, Max. - maximum, SD - standard deviation,

$p$ - materiality level.

*中 < 0,05; K - kobiety, M - mężczyźni, N - liczba osób, Med. - mediana, Min. - minimum, Max. - maksimum, SD - odchylenie standardowe,

p- poziom istotności. 
Table 4. Correlations between life quality and body image dimensions vs. illness duration

Tabela 4. Korelacje między jakościq życia i mymiarami obrazu własnego ciała a czasem trwania choroby

\begin{tabular}{lc} 
Body appearance evaluation accessed by MBSRQ and perceived quality of life accessed by DLQI and illness duration \\
(since the diagnosis)/Ocena wyglądu własnego ciała w MBSRQ i poczucie jakości życia na podstawie DLQI a czas \\
trwania choroby (od momentu diagnozy) & $r$ \\
\hline Appearance Evaluation/Ocena Wyglądu & -0.03 \\
\hline Appearance Orientation/Zorientowanie na Wygląd & $0.27^{*}$ \\
\hline Fitness Evaluation/Ocena Sprawności & 0.11 \\
\hline Fitness Orientation/Zorientowanie na Sprawność & 0.03 \\
\hline Health Evaluation/Ocena Zdrowia & $-0.35^{*}$ \\
\hline Health Orientation/Zorientowanie na Zdrowie & 0.24 \\
\hline Illness Orientation/Zorientowanie na Choroby & 0.17 \\
\hline Body Areas Satisfaction/Satysfakcja z Obszarów Ciała & -0.13 \\
\hline Overweight Preoccupation/Zaabsorbowanie Nadwagą & 0.03 \\
\hline Self-classified Weight/Ocena Własnej Wagi & -0.01 \\
\hline Perceived quality of life accessed by DLQI/poczucie jakości życia na podstawie DLQI & $0.29 *$ \\
\hline *p < 0.05; $p$ - materiality level, $r$ - correlation coefficient. &
\end{tabular}

dimensions of body image - Appearance Orientation $(r=0.27)$ and Health Evaluation $(r=-0.35)-$ was examined (Table 4 ).

\section{DISCUSSION}

Skin is the most visible organ, and therefore it constitutes an important element that shapes one's body image, self-assessment, self-acceptance, self-esteem, and perceived quality of life. If this vital organ is damaged or distorted, it negatively affects the person's well-being and leads to deterioration of his or her life quality $[16,17]$. Dermatological diseases often lead to changes in the appearance of the affected person, and this may contribute to developing a negative body image, which is accompanied by shame, anxiety, helplessness, guilt and stigmatization [18]. A disfigured body and a conviction of being physically unattractive, lack of acceptance and understanding from others that is observed by AD patients, unpleasant ailments such as itching, pain and burning sensations, as well as the constant necessity to use medicinal products, lead to deterioration of life quality [16, 18-20].

The research study described here revealed that AD patients' life quality was affected by individual dimensions of body image. The disease was experienced as more troublesome when patients assessed their bodies as less healthy and prone to unfavourable changes and ailments. Both dissatisfaction with one's body appearance and a negative attitude to its individual areas contributed to deterioration of life quality in the context of experiencing the related ailments. It was established that the disease to a larger extent impaired the life of those AD patients who paid considerable attention to their appearance miary oceny obrazu własnego ciała: Zorientowanie na Wygląd $(r=0,27)$ i Ocena Zdrowia $(r=-0,35)$ (tabela 4$)$.

\section{OMÓWIENIE}

Skóra jest narządem widocznym dla otoczenia i dlatego stanowi ważny element wpływający na obraz siebie, samoocenę, poczucie własnej wartości i jakość życia. Jeśli ten organ jest uszkodzony lub zniekształcony, godzi to w samopoczucie i wpływa na pogorszenie jakości życia danej osoby [16, 17]. Choroby dermatologiczne często prowadzą do zmian w wyglądzie człowieka i mogą się przyczyniać do ukształtowania negatywnego obrazu własnego ciała, czemu towarzyszą: wstyd, lęk, niepokój, bezradność, poczucie winy i stygmatyzacji [18]. Oszpecone ciało, przekonanie o nieatrakcyjności fizycznej, brak akceptacji i zrozumienia ze strony innych ludzi doświadczane przez pacjentów z AZS, przykre dolegliwości fizyczne, takie jak świąd, ból i pieczenie, oraz konieczność codziennego stosowania środków medycznych powodują obniżenie jakości życia [16, 18-20].

Na podstawie przeprowadzonego badania stwierdzono, że u osób chorych na AZS ocena poszczególnych aspektów obrazu własnego ciała wpływa na poczucie jakości życia. Choroba jest przeżywana jako bardziej dotkliwa, gdy pacjenci oceniają swoje ciało jako mniej zdrowe oraz podatne na niekorzystne modyfikacje i schorzenia. Zarówno niezadowolenie z wyglądu własnego ciała, jak i negatywne ustosunkowanie się do poszczególnych jego obszarów wiąże się z obniżeniem jakości życia w kontekście doświadczanych dolegliwości. Wykazano, że choroba bardziej upośledza życie tych osób z AZS, które przykładają dużą wagę do dbałości o swój wygląd 
and health, and tended to abide by healthy lifestyle principles. Such persons may feel highly frustrated with the ineffectiveness of their activities focused on fighting the disease, and also experience helplessness as subsequent symptoms develop. Moreover, AD patients state that they often encounter negative reactions of other people, which increases their feelings of stigmatization and reinforces their conviction of being physically unattractive. Consequently, they may overstate their ailments and limitations connected with the disease, starting with preoccupation with and focusing on masking the skin lesions with appropriate make-up and clothes, and ending with purposeful refraining from establishing and maintaining interpersonal contacts and sexual relationships. These findings are consistent with other authors' research results which indicated that patients with a negative self-image assessed the state of their mental health and life quality differently from the patients with a positive self-image $[7,8,18]$.

Not only the media but also comparative studies regarding dissatisfaction with one's body appearance indicate that women are more critical than men in this respect $[10,19-22]$. Here we must mention the "feminine beauty myth" that is communicated to girls in the course of the socialization process. According to this myth, a woman may have a successful life thanks to her bodily attractiveness. This is the source of the common views that women identify with their bodies much more strongly than men, they care more for their looks and become more stressed when their skin condition deteriorates [10]. This study did not show such differences between the women and the men, which is consistent with the results of some other studies [19, 23], as well as with the observed metrosexual trend. It should be noted that Polish men cared for their looks to the same degree women did, and that caring for oneself and use of cosmetics by men was more and more often socially accepted. Analogously to the above described findings, no significant differences were found between female and male AD patients in terms of life quality assessment. Therefore, the obtained results confirm the hypothesis that being less happy with one's body appearance is associated with lower life quality, regardless of gender.

Even though the female and male subjects assessed their life quality and general body image similarly, the women showed stronger fear of obesity and more interest in their weight. The women also proved to be more conscious of their health and more engaged in adhering to healthy lifestyle principles. In western culture, slenderness has long been associated with concepts such as happiness, success, youthfulness and being socially accepted [24]. Overweight and obesity show no such associations, as they are commonly attributed to laziness and lack of strong will. Attitude i zdrowie oraz starają się prowadzić zdrowy styl życia. Takie osoby mogą odczuwać silną frustrację z powodu nieskuteczności działań ukierunkowanych na walkę z chorobą, a także doświadczać bezradności wobec pojawiania się jej kolejnych objawów. Ponadto chorzy na AZS sygnalizują, że często spotykają się z negatywnymi reakcjami ze strony innych ludzi, co wzmacnia już obecne poczucie stygmatyzacji oraz utwierdza ich w przekonaniu o własnej nieatrakcyjności fizycznej. W konsekwencji mogą oni nieproporcjonalnie przeżywać dolegliwości i ograniczenia związane z chorobą, poczynając od nadmiernej koncentracji na maskowaniu zmian skórnych za pomocą odpowiedniego makijażu i ubioru, a kończąc na celowym odstępowaniu od nawiązywania oraz utrzymywania kontaktów interpersonalnych i związków intymnych. Te ustalenia są spójne z wynikami badań innych autorów, którzy wskazują, że pacjenci z negatywnym obrazem siebie oceniają stan swojego zdrowia psychicznego oraz jakość życia niżej niż pacjenci z pozytywnym obrazem siebie $[7,8,18]$.

Nie tylko środki masowego przekazu, lecz także badania porównawcze dotyczące niezadowolenia z wyglądu własnego ciała informują, że kobiety są bardziej krytyczne pod tym względem niż mężczyźni [10, 19-22]. Zwraca się tu uwagę na kulturowy mit kobiecego piękna, zgodnie z którym kobieta może osiągnąć sukces dzięki pięknu swego ciała. Stąd biorą się powszechne opinie, że kobiety o wiele silniej identyfikują się ze swoim ciałem niż mężczyźni oraz doświadczają silniejszego stresu z powodu pogorszenia stanu skóry [10]. W przeprowadzonym badaniu nie wykazano takich różnic pomiędzy kobietami i mężczyznami, co jest spójne zarówno z wynikami niektórych badań [19, 23], jak i ze współcześnie obserwowanym trendem metroseksualnym. Należy zauważyć, że mężczyznom zależy na wyglądzie w podobnym stopniu jak kobietom oraz że dbałość o siebie i używanie kosmetyków przez mężczyzn coraz częściej spotyka się ze społeczną akceptacją. W przeprowadzonym badaniu również nie zaobserwowano istotnych różnic pomiędzy kobietami i mężczyznami chorymi na AZS w zakresie oceny jakości własnego życia. Otrzymane wyniki potwierdzają więc hipotezę, że mniejsze zadowolenie z wyglądu ciała wiąże się z niższą oceną jakości życia, niezależnie od płci.

Chociaż kobiety i mężczyźni podobnie oceniają ogólny obraz własnego ciała, to kobiety przejawiały silniejszy lęk przed otyłością i większe zainteresowanie masą ciała. Okazały się też bardziej świadome stanu swego zdrowia i silniej zaangażowane w realizację zasad zdrowego stylu życia. W krajach kultury zachodniej od dawna szczupłość wiązana jest z takimi pojęciami, jak: szczęście, sukces, młodzieńczość i bycie akceptowanym społecznie [24]. Daleko od tych wartości znajdują się nadwaga i otyłość, które powszechnie łączy się z lenistwem i brakiem silnej 
to weight and consequently to following a healthy lifestyle is particularly important in the process of female body image development [21]. It was observed that women tend to monitor their weight systematically and they diet far more often than men [24]. It is also worth mentioning that it is mainly women who are active users of websites and internet forums dedicated to AD patients. They support and advise each other, focusing on the everyday fight with skin lesions. Moreover, the European Health Interview Survey (EHIS), conducted by the Central Statistical Office in 2015 [25], showed unambiguously that, compared to men, women more often availed themselves of medical services and took appropriate medication and preventive measures. The survey results confirm the predominant trends in the general population, as it is the female AD patients who worry more about their weight, fight obesity more often and show more concern for their health, which is proof that health is very important to them $[22,26,27]$.

This study also showed that the illness duration affected the AD patients' life quality and that it played an important role with respect to body image dimensions such as Appearance Orientation and Health Evaluation. Thus, it was confirmed that as the disease duration increased, the life quality decreased $[8,28,29]$, accompanied by more and more intensive feelings of helplessness and dissatisfaction with one's health and intensified care for external appearance. AD patients battle against the disease for many years and even the whole life, making immense day-to-day efforts to get rid of symptoms of the disease and mitigate the suffering. Due to the chronic nature of the disease, it is experienced as exceptionally onerous and hard to treat, and efforts taken to fight it are seen as hardly effective. Consequently, sooner or later AD patients come to the conclusion that even though they have no control over the course of their disease, at least they can have an influence on their own looks. AD patients are additionally motivated to take care of their physical appearance in order to avoid or mitigate any negative, stigmatizing reactions often encountered by dermatological patients.

\section{CONCLUSIONS}

This study demonstrated that the AD patients who pay more attention to health and healthy lifestyle are more exposed to experiencing unpleasant ailments connected with this dermatitis. Therefore, apart from the conventional treatment procedures, it would be advisable to apply systematic education regarding the disease and its treatment [30]. In the course of education, special emphasis should be placed on the knowledge of factors that exacerbate the disease and on expanding the knowledge about prevention. Approxi- woli. Stosunek do masy ciała, a w związku z tym do dbałości o zdrowy styl życia, ma szczególne miejsce w obrazie kobiecego ciała [21]. Zaobserwowano, że kobiety raczej systematycznie monitorują swoją wagę i stosują diety odchudzające o wiele częściej niż mężczyźni [24]. Warto dodać, że to głównie kobiety udzielają się na forach i stronach internetowych zrzeszających osoby chorujące na AZS. Dają sobie wzajemne wsparcie i udzielają porad, a ich uwage przykuwa codzienna walka ze zmianami na skórze. Ponadto Europejskie Ankietowe Badania Zdrowia (EHIS) przeprowadzone przez Główny Urząd Statystyczny w 2015 r. [25] jednoznacznie wykazały, że kobiety częściej niż mężczyźni korzystały z usług medycznych, częściej niż oni zażywały leki oraz dbały o profilaktykę. Wyniki przeprowadzonego badania potwierdzają trendy dominujące w populacji ogólnej, ponieważ to właśnie kobiety chore na AZS bardziej niż mężczyźni martwią się o wagę, częściej podejmują walkę z otyłością i wykazują większą dbałość o zdrowie, co dowodzi, że stanowi ono dla nich ważną wartość [22, 26, 27].

$\mathrm{Na}$ podstawie przeprowadzonego badania stwierdzono, że czas trwania choroby wpływa na jakość życia osób chorych na AZS oraz że czas trwania choroby odgrywa ważną rolę $\mathrm{w}$ odniesieniu do takich wymiarów obrazu ciała, jak zorientowanie na wygląd i ocena zdrowia. Tym samym potwierdzono, że wraz z czasem trwania choroby obniża się jakość życia [8, 28, 29], wzrasta poczucie bezradności i niezadowolenie ze stanu zdrowia oraz zwiększa się dbałość o wygląd zewnętrzny. Pacjenci z AZS przez wiele lat, a czasem przez całe życie podejmują ogromny, codzienny wysiłek, aby pozbyć się objawów chorobowych i zminimalizować swe cierpienie. Przewlekły charakter choroby sprawia, że jest ona doświadczana jako wyjątkowo uciążliwa i trudna do wyleczenia, a podejmowane wysiłki są oceniane jako mało skuteczne. Osoby z AZS wcześniej czy później dochodzą do przekonania, że chociaż nie mają możliwości kontrolowania przebiegu choroby, to przynajmniej mogą mieć wpływ na swój wygląd. Dodatkowo do większej dbałości o wygląd fizyczny skłania chęć uniknięcia bądź zminimalizowania negatywnych i piętnujących reakcji, z jakimi często spotykają się pacjenci z chorobami dermatologicznymi.

\section{WNIOSKI}

Przeprowadzone badanie wykazało, że pacjenci z AZS przejawiający większą dbałość o zdrowie i zdrowy styl życia są bardziej narażeni na doświadczanie przykrych dolegliwości związanych z tą dermatozą. Warto zatem uwzględnić, obok konwencjonalnego postępowania, systematyczną edukację dotyczącą choroby i sposobów jej leczenia [30]. W trakcie edukacji szczególny nacisk należy położyć na znajomość czynników zaostrzających chorobę oraz na poszerza- 
mation of the patient's idea of the course of the disease to the disease image diagnosed by the physician has a positive impact on the patient's mental state and reinforces his or her pro-health behaviour [17]. Treatment of dermatological diseases should be supported by an element of psychotherapy focused on lowering the level of fear of stigmatization due to the disease and its symptoms. It should also aim at changing any incorrect mental patterns regarding the patient's body image and self-acceptance and at reinforcing the motivation to take an active part in the treatment process [2].

\section{CONFLICT OF INTEREST}

The authors declare no conflict of interest. nie wiedzy z zakresu profilaktyki. Zbliżenie wyobrażeń pacjenta na temat przebiegu choroby do obrazu stwierdzanego przez lekarza wpływa korzystnie na stan psychiczny chorego i wzmacnia zachowania prozdrowotne [17]. W leczeniu chorób skóry stałym elementem wspomagającym powinny być oddziaływania terapeutyczne ukierunkowane na obniżenie poziomu lęku przed stygmatyzacją z powodu choroby i jej objawów. Należy też dążyć do zmiany nieprawidłowych wzorców mentalnych dotyczących obrazu własnego ciała i do jego akceptacji oraz wzmocnienia motywacji do aktywnego uczestnictwa w procesie leczenia [2].

\section{KONFLIKT INTERESÓW}

Autorzy deklarują brak konfliktu interesów.

\section{References \\ Piśmiennictwo}

1. Jenerowicz D.: Atopowe zapalenie skóry. [In:] Psychologiczne i medyczne aspekty chorób skóry (Psychological and medical aspects of skin diseases). T. Rzepa, J. Szepietowski, R. Żaba (eds.). Cornetis, Wrocław, 2011, 183-191.

2. Kłudkowska J., Nowicki R.: Wpływ atopowego zapalenia skóry na jakość życia pacjentów i ich rodzin. Alergia Astma Immunologia 2013, 18, 21-24.

3. Żelazny I., Nowicki R., Majkowicz M., Samet A.: Jakość życia w chorobach skóry. Przew Lek 2004, 9, 60-65.

4. Bartoszek B.: Atopowe zapalenie skóry (AZS) jako choroba psychosomatyczna: analiza badań (Atopic dermatitis as a psychosomatic illness: an analysis of research). Studia z Psychologii KUL 2010, 16, 57-74.

5. Cash T.F.: Body image: past, present, and future. Body Image 2004, 1, 1-5.

6. Goffman E.: Piętno (Stigma). Gdańskie Wydawnictwo Psychologiczne, Gdańsk, 2005.

7. Kasznia-Kocot J., Rechmann K., Wypych-Ślusarska A.: Wybrane aspekty jakości życia w atopowym zapaleniu skóry. Medycyna Środowiskowa/Environmental Medicine 2014, 17, 42-51.

8. Kiebert G., Sorensen S.V., Revicki D., Fagan S.C., Doyle J.J, Cohen J., et al.: Atopic dermatitis is associated with a decrement in health-related quality of life. Int J Dermatol 2002, 41, 151-158.

9. Zuberbier T., Orlow S.J., Paller A.S., Taieb A., Allen R., Hernanz-Hermosa J.M., et al.: Patient perspectives on the management of atopic dermatitis. J Allergy Clin Immunol 2006, 118, 226-232.

10. Cash T.F., Smolak L.: A Handbook of Science, Practice and Prevention. The Guilford Press, New York, 2011.

11. Thompson A.R.: Body image issues in dermatology. [In:] A handbook of Science, Practice and Prevention. T. F. Cash, L. Smolak (eds.), The Guilford Press, New York, 2011, 323-332.

12. Cash T.F.: The multidimensional body-self relations questionnaire. MBSRQ users' manual. Old Dominion University, Norfolk, 2000

13. Rzeszutek M., Schier K.: Tak bolesne, że aż obce? Związek pomiędzy depresją a obrazem ciała u młodych dorosłych. Psychoterapia 2008, 4, 5-16.

14. Finlay A.Y., Khan G.K.: Dermatology Life Quality Index (DLQI) - a simple practical measure for routine clinical use. Clin Exp Dermatol 1994, 19, 210-216.

15. Szepietowski J., Salomon J., Finlay A.Y., Klepacki A., Chodynicka B., Marionneau N., et al.: Wskaźnik wpływu dolegliwości skórnych na jakość życia - Dermatology Life Quality Index (DLQI): polska wersja. Dermatol Klin 2004, 6, 63-70.

16. Cash T., Fleming E.C.: The impact of body image experiences: development of the body image quality of life inventory. Int J Eat Disord 2001, 31, 455-460.

17. Kmieć M.L., Broniarczyk-Dyła G.: Aspekty psychologiczne związane z atopowym zapaleniem skóry. Dermatol Klin 2009, 11, 237-240.

18. Potocka A., Turczyn-Jabłońska K., Kieć-Świerczyńska M.: Self-image and quality of life of dermatology patents. Int J Occup Med Environ Health 2008, 21, 309-317.

19. Zarek A.: Obraz ciała w ujęciu procesu lub obiektu a satysfakcja z własnego ciała (Body image as a process or object and body satisfaction). Roczniki Pomorskiej Akademii Medycznej w Szczecinie/Annales Academiae Medicae Stetinensis 2009, 55, 100-106.

20. Zarek A.: Czynniki kształtujące obraz ciała u osób z wybranymi chorobami dermatologicznymi (Factors influencing body image in individuals with selected dermatological diseases). Roczniki Pomorskiej Akademii Medycznej w Szczecinie/Annales Academiae Medicae Stetinensis 2014, 60, 75-87.

21. Schier K.: Piękne brzydactwo (Beautiful ugly one). Wydawnictwo Naukowe Scholar, Warszawa, 2009.

22. Mirucka B., Sakson-Obada O.: Ja cielesne. Od normy do zaburzeń (I bodily. From the norm to disorders). Gdańskie Wydawnictwo Psychologiczne, Sopot, 2013.

23. Byrtek-Matera A.: Obraz ciała - obraz siebie (Body image - image of oneself). Difin, Warszawa, 2008.

24. Grogan S.: Body image: understanding body dissatisfaction in men, women, and children. Taylor and Francis Group, London, New York: Routledge, 2008. 
25. Zdrowie i zachowanie zdrowotne mieszkańców Polski w świetle Europejskiego Ankietowego Badania Zdrowia (EHIS) 2014. Główny Urząd Statystyczny, Warszawa 2015.

26. Holm E.A., Esmann S., Jemec G.B.E.: Does visible atopic dermatitis affect quality of life more in women than in men? Gend Med 2004, 1, 125-130.

27. Tantleff-Dunn S., Barnes R.D., Gokee La Rose J.: It's not just a "woman thing": the current state of normative discontent. Eating Disorders 2011, 19, 391-402.

28. Noor Aziah S., Rosnah T., Mardziah A., Norzila M.Z.: Childhood atopic dermatitis: a measurement of quality of life and family impact. Med J Malaysia 2002, 57, 329-339.

29. Kim D.H., Li K., Jun Seo S., Jin Jo S., Woo Yim H., Min Kim C., et al.: Quality of life and disease severity are correlated in patients with atopic dermatitis. J Korean Med Sci 2012, 27, 1327-1332.

30. Staab D., Diepgen T.L., Fartasch M., Kupfer J., Lob-Corzilius T., Ring J., et al.: Age related, structured educational programmes for the management of atopic dermatitis in children and adolescents: multicentre, randomised controlled trial. BMJ 2006, 22, 933-938.

Received: 11.10 .2016

Accepted: 9.04.2017

Otrzymano: 11.10 .2016 r.

Zaakceptowano: 9.04 .2017 r.

How to cite this article

Mikołajczyk J., Rzepa T., Król J., Żaba R.: Body image assessment and quality of life in patients with atopic dermatitis. Dermatol Rev/Przegl Dermatol 2017, 104, 92-102. DOI: https://doi.org/10.5114/dr.2017.67383 